\title{
PARÁDI Ákos
}

\section{Bosznia-Hercegovina csendőrsége az Osztrák-Magyar Monarchia időszakában}

Bosznia-Hercegovinát az Osztrák-Magyar Monarchia 1878-ban okkupálta, majd 1908-ban annektálta, melynek következtében a török szultán névleges fennhatósága is megszűnt a tartomány felett. BoszniaHercegovinát azonban a két társország egyikéhez sem, azaz az Osztrák Császársághoz, illetve a Magyar Királysághoz sem csatolták, hanem a két társország közösen kormányozta a közös pénzügyminiszter által. ${ }^{1}$

A tartományban az életet az Osztrák-Magyar Monarchia belső viszonyaihoz igazították. A polgári viszonyok az Osztrák-Magyar Monarchia szabályai szerint honosodtak meg Bosznia-Hercegovinában, amely az annexió nyomán 1910-ben alkotmányt is kapott melyet Ferenc József uralkodói pátenssel hatályosított. $^{2}$

A tartományra tehát az Osztrák-Magyar Monarchia viszonyait adaptálták. Ennek megfelelően a közigazgatás és annak részeként a rendvédelem a tartomány belső ügyének minősült, mint ahogyan a két társország, nevezetesen az Osztrák Császárság és a Magyar Királyság esetében is. ${ }^{3}$ A különbség „csupán” annyi volt, hogy a Magyar Királyság, illetve az Osztrák Császárság esetében a két társország kormányának, illetve törvényhozó testületének már nem volt felettes szervezete, azonban BoszniaHercegovina esetében a tartományi közigazgatás és annak részeként a rendvédelem legfőbb igazgatási és felügyeleti teendöit a közös pénzügyminiszter látta el az osztrák és a magyar országgyülés intencióinak megfelelően. ${ }^{4}$

Bosznia-Hercegovina közigazgatását tehát a dualizmus gyakorlatának megfelelően rendezték, a hadügy témáját pedig az uralkodói felségjog szellemében intézték. Ebbe az osztrák és a magyar alkotmányos szervek nem szólhattak bele. A rendezés módja pedig megegyezett az Osztrák-Magyar Monarchia mindkét társországában már korábban bevezetettekkel. A tartomány területét kerületekre osztották, amelyek férfi lakossága alkotta a közös hadsereg területileg illetékes ezredeinek legénységi utánpótlását az általános hadkötelezettség elvének megfelelően. ${ }^{5}$

A Bosznia-Hercegvina-i csendőrség nem tartozott sem az osztrák, sem pedig a magyar csendőrséghez. A tartomány csendőrsége Bosznia-Hercegovina kormánya belügyminiszterének a felügyelete alatt állt, mivel a rendvédelem a belügyi tárca kompetenciájába tartozott. Azonban a bosnyák csendőrség is katonailag szervezett örtestület volt, hasonlóan az Osztrák-Magyar Monarchia két társállamának csendőrségéhez. Ebből fakadóan pedig - mivel a csendőr személyében katonának minősült - a bosnyák csendőrség személyi ügyekben a közös haderőhöz tartozott. Az összes többi témában azonban a bosnyák kormány felügyelete és irányítása alatt állt a testület, melyet a kormány a belügyminiszter által gyakorolt. A helyzet tehát — a testület és a személyi állomány jogállását illetően is — lényegében azonos volt a magyarországival azzal a különbséggel, hogy a Magyar Királyi Csendőrség személyi állománya a honvédelmi tárcához tartozott, ahol a testületi tagok ügyeinek az intézése céljából külön osztály müködött, míg a bosnyák csendőrség személyi állománya a közös hadsereg területileg illetékes magasabb parancsnokságához tartozott. ${ }^{6}$

Végső soron tehát valamennyi csendőrség személyi állományának az ügyei a haderőhöz tartoztak, azonban eltérő módon. A haderő ugyanis két haderő nemből állt a tengerészetből és a szárazföldi eröböl. Léteztek ugyan már repülök is — föleg a világháború időszakában — azonban még nem alkottak önálló haderőnemet. A repülősöket légjáró csapatnak hívták, belőlük alakult ki a későbbi idők légiereje. A tengerészet teljes egészében a közös haderő része volt. A szárazföldi csapatok legerősebb részét is a közös haderő alkotta. E haderő azonban kiegészült a Magyar Királyságban a Magyar Királyi Honvédséggel és a népfelkeléssel, az Osztrák Császárságban pedig a Landwehr-el és a Landstrum-al. A Magyar Királyi Honvédségnek és a népfelkelésnek, illetve a Landwehr-nek és a Landstrum-nak nem voltak magasabb egység-parancsnokságaik és nehézfegyverzetük, illetve a fegyvernemek egy részével sem rendelkeztek, hanem a közös hadsereg magasabb egység-parancsnokságainak az alárendeltségébe tartoztak. A teljes haderö felett Ferenc József - a magyar kiegyezési törvényben foglaltak szerint — „mint alkotmányos fejedelmi jogot” gyakorolta a vezérlet $=$ Leitung, vezénylet $=$ Führung és belszervezet $=$ innere Organisation jogokat. Ehhez a haderöhöz illeszkedtek — a két társország és a tartomány sajátosságainak megfelelően — a csendőrségek. ${ }^{7}$

A Bosznia-Hercegovina-i csendőrség lényegében egy magyar csendőr kerületnek felelt meg. A terület nagysága, a müködési területen élö lakosság létszáma, illetve a személyi állomány létszáma is a Magyar Királyi Csendőrség kerületeihez volt hasonló. A tartományi csendőrség szervezeti felépítése a testület müködése, a szervezet irányításának az elvei, a személyi állomány jogállása stb. azonos, vagy nagyon hasonló volt a Magyar Királyi Csendőrségéhez. 
A testület parancsnoksága - ahogyan azt a tartományban nevezték a „,csendörkar-parancsnokság”- a tartomány székhelyére - ahol a közigazgatás szervezeteinek központjai is müködtek Szarajevóba települt. A testületi parancsnokság — amelyet a Magyar Királyságban csendőr felügyelöségnek hívtak - alárendeltségébe két alsóbb szintủ tiszti parancsnokság tartozott, amelyek irányítása alatt pedig az őrsök teljesítettek szolgálatot. Összességében tehát a Bosznia-Hercegovina-i csendőrség négy szintü testület volt (I.sz. melléklet). A tartományi csendőrségre is jellemző volt — ugyanúgy mint a Magyar Királyi Csendőrségre - hogy tisztek csak a parancsnokságokon teljesítettek szolgálatot csekély létszámmal. A testület személyi állományának a többségét pedig - mintegy 90 \%-os aránynyal — a legénység alkotta, akik az örsökön látták el szolgálati feladataikat. ${ }^{9}$

A csendőr kar-parancsnokságon teljesített szolgálatot a testület parancsnoka és helyettese tábornoki és ezredesi rendfokozatban, három fö törzstiszt alezredesi rendfokozatban, két fö beosztott tiszt századosi ranggal akik az oktatást és a fegyverzetet felügyelték, melléjük segítőként beosztva egy-egy altiszt, egy fö gazdászati tiszt, egy fő puskamüves (fegyvermester) altisztként és egy fö segítője tisztesként, egy fő törzsvezető, aki a tisztiszolgákat és a tisztek lovainak ellátását továbbá általában a fuvarozást felügyelte, valamint hat fő segédmunkás. A testületi parancsnokság teljes létszáma tehát a tisztiszolgákat is beleértve - összesen csupán 21 fö volt. ${ }^{\mathbf{1 0}}$

A szárny-parancsnokságok a testület vezető szervezetének az alárendeltségében müködtek. Összesen nyolc szárny-parancsnokság múködött. ${ }^{11}$

A szárny-parancsokságon teljesített szolgálatot a szárny-parancsnok törzstiszti rangban (őrnagy vagy alezredes), egy fő gazdásztiszt beosztott tiszti rangban (hadnagy vagy föhadnagy, esetleg százados), egy fő számvivő altiszt és két fö irodai szolgálatot ellátó altiszt. Egy szárny-parancsnokságon tehát — a tiszti szolgákat is figyelembe véve — összesen 7 fó teljesített szolgálatot. Ebben a létszámban azonban nem szerepelnek a segédmunkások mivel az alkalmazásuk nem folyamatos, hanem esetenkénti volt. ${ }^{12}$

A szakasz-parancsnokság volt a testületen belüli a legalacsonyabb szintü tiszti parancsnokság. A szakasz-parancsnokságon teljesített szolgálatot a szakasz-parancsnok főhadnagyi vagy századosi rangban. A szakasz-parancsnoksági teendőket egyszemélyben látta el. Ez a legalsó szintű parancsnokság - a tiszti szolgát is számításba véve - két fös volt. Nem tartozott ugyan a parancsnokság személyi állományába, azonban a szakasz-parancsnok hosszabb távolléte esetében — betegség, szabadság stb. - a szakasz-parancsnok székhelyein szolgálatot teljesítő járásőrmesterek helyettesítették más teendőik ellátása mellett. Ilyenkor a minősített ügyek esetében pedig a szomszédos szakasz-parancsnokok helyettesítették a távollévő tiszttársukat. Összesen 27 szakasz-parancsnokság müködött. ${ }^{13}$

A testület parancsnokságainak az elhelyezkedését illetően tehát a rendező elv azonos volt a Magyar Királyi Csendőrségnél alkalmazottakkal. Eszerint a magasabb szintű parancsnokságok székhelyén mindig diszlokált az alárendelt parancsnokságok közül egy. Ennek az alapelvnek képezte a részét az is, hogy a tiszti parancsnokságok székhelyeire mindig telepíteni kellett egy csendőr örsöt is. ${ }^{14}$

A csendör örs volt a tartományi csendőrség legkisebb szervezeti eleme, hasonlóan a magyar és az osztrák csendőrséghez, illetve ez volt a jellemző általában a csendőr szervezettípusra. Az őrsök személyi állományában már csak altisztek és tisztesek teljesítettek szolgálatot. Az őrsök tevékenységét az őrs-parancsnokok irányították, őket az őrs-parancsnokhelyettesek támogatták a munkájukban. Az őrsökön szolgálatot teljesített még rajtuk kívül átlag hat-nyolc fö. Bosznia-Hercegovinában összesen 267 őrs működött. Nagyobb létszámú - mintegy 12-16 fős - őrsöket csupán a járások székhelyeire telepítettek abból a célból, hogy ha valamely őrsön a létszám négy fő alá süllyedne legyen honnan csendőrt vezényelni az érintett őrsre, illetve ezen őrsök létszámát kívánták karhatalmi feladatok ellátására is igénybe venni. ${ }^{15}$

A testület személyi állományának a képzési rendszere érdekesen alakult a Magyar Királyi Csendőrségéhez képest. Eredetileg ugyan a magyar csendőrségnél is a képzési centrumok többé-kevésbé a parancsnokságok mellett létesültek, azonban viszonylag hamar — már a századforduló időszakára — létrejöttek azok az oktatási szervezetek, amelyek a testület egésze számára valósították meg a szakmai felkészítést. ${ }^{16}$ Lényegében azonosak voltak azonban a képzési formák, mivel mindkét csendőrségnél létezett a legénység alapfelkészítése. Erre épült — néhány évi szolgálati tapasztalat megszerzése nyomán - a járőrvezetői tanfolyam. A legénységi képzés csúcsát az őrs-parancsnok képző tanfolyam alkotta. A három színtü csendőr legénységi képzés illetve továbbképzés mellett müködött a gazdászképzés, melyet a haderő gazdászképző oktatási intézményeinek az elvégzésével valósítottak meg. ${ }^{17}$

A testület tiszti karába pedig az Osztrák-Magyar Monarchia haderejének azon tisztjei kérhették a felvételüket, akik már legalább ötéves csapatszolgálattal rendelkeztek, vagy — tekintet nélkül a szolgálati időre - magyar, illetve osztrák csendőrtisztek voltak. Valamennyi jelentkezőnek beszélnie kel- 
lett német és valamilyen szláv nyelven is. A Bosznia-Hercegovina-i csendőrségnél az átvett tiszteknek egyéves próbaszolgálatot kellett teljesíteniük, melynek a végén gyakorlati vizsgán minősítették őket. Az eredményes vizsgán átesett tiszteket véglegesítették a testületnél. A próbaszolgálatot a szárny-parancsnokságokon teljesítették, ahol a mentoruk a szárny-parancsnok volt. Ez a rendszer kísértetiesen hasonlított a magyarra, ahol a fiatal tisztek a Ludovika Akadémia elvégzését követően elméleti és gyakorlati tartalmú szakképzés nyomán kerültek az első tiszti beosztásukba, amely azonban még nem volt önálló tisztség, hanem a legkisebb tiszti beosztás helyettesi helye, ahol az idősebb tiszttársuktól eltanulhatták a szakterület fortélyait. ${ }^{18}$ (II.sz. melléklet)

A csendőr legénység számára szállást a testület az őrsökön biztosított. Örsönként egy fő csendőr nösülését engedélyezték. Neki viszont nem volt szabad az örsön laknia. Családja lakhatási költségeit pedig a testület fedezte. A testület tagjai számára térítésmentesen biztosították a fegyvert, lőszert és ruházatot, valamint az ágynemüt és az őrslaktanyát, a többiről pedig a legénységnek a zsoldjából kellett gondoskodnia. Az őrs épületében - amelyek lehettek kincstári tulajdonban, vagy bérlemény-ként használhatták azokat — az őrs-parancsnoknak és helyettesének külön-külön szoba járt, a többi csendőr pedig kettő-négy ágyas szobákban lakott. Minden őrsön volt továbbá irodahelység, étkező, konyha, kamra és egy társalgó. Az őrsfőzőnő, a mosókonyha a melléképületben kapott helyet más mellékhelységek társaságában. ${ }^{19}$

A Bosznia-Hercdegovina-i csendőrség is rendelkezett - a Magyar Királyi Csendőrséghez hasonlóan - a személyi állomány szociális helyzetének javítását célzó intézményekkel. Az egyiket Bosznia-Hercegovina kormánya hozta létre alapítványi formában. Ennek az volt a célja, hogy az alaptvány hozadékából évente megjutalmazzák a legkiválóbb járőrvezetőket. Ferenc József is létrehozott egy csendőrségi alapítványt a testület altisztjeinek a segélyezése céljából. Hasonló alapítványok a Magyar Királyságban is müködtek. ${ }^{\mathbf{2 0}}$

A Bosznia-Hercegovina-i csendőrségnek volt egy speciális — a Magyar Királyi Csendőrség, illetve a magyar határőrizet tekintetében - lényeges momentuma is. Nevezetesen a magyar határszéli csendőrség 1912. évi átszervezését megelőzően OLÁH Ödön vezetésével csendőr tiszti delegációt küldtek ki Bosznia-Hercegovinába és az Osztrák Császárság örökös tartományaiba, hogy tanulmányozzák az ottani határőrizeti struktúrát. A tanulmányút tapasztalatait a csendőr tiszti delegáció jelentésben foglalta össze. E tapasztalatokat hasznosította a magyar állam a határszéli csendőrség átszervezése során. ${ }^{21}$

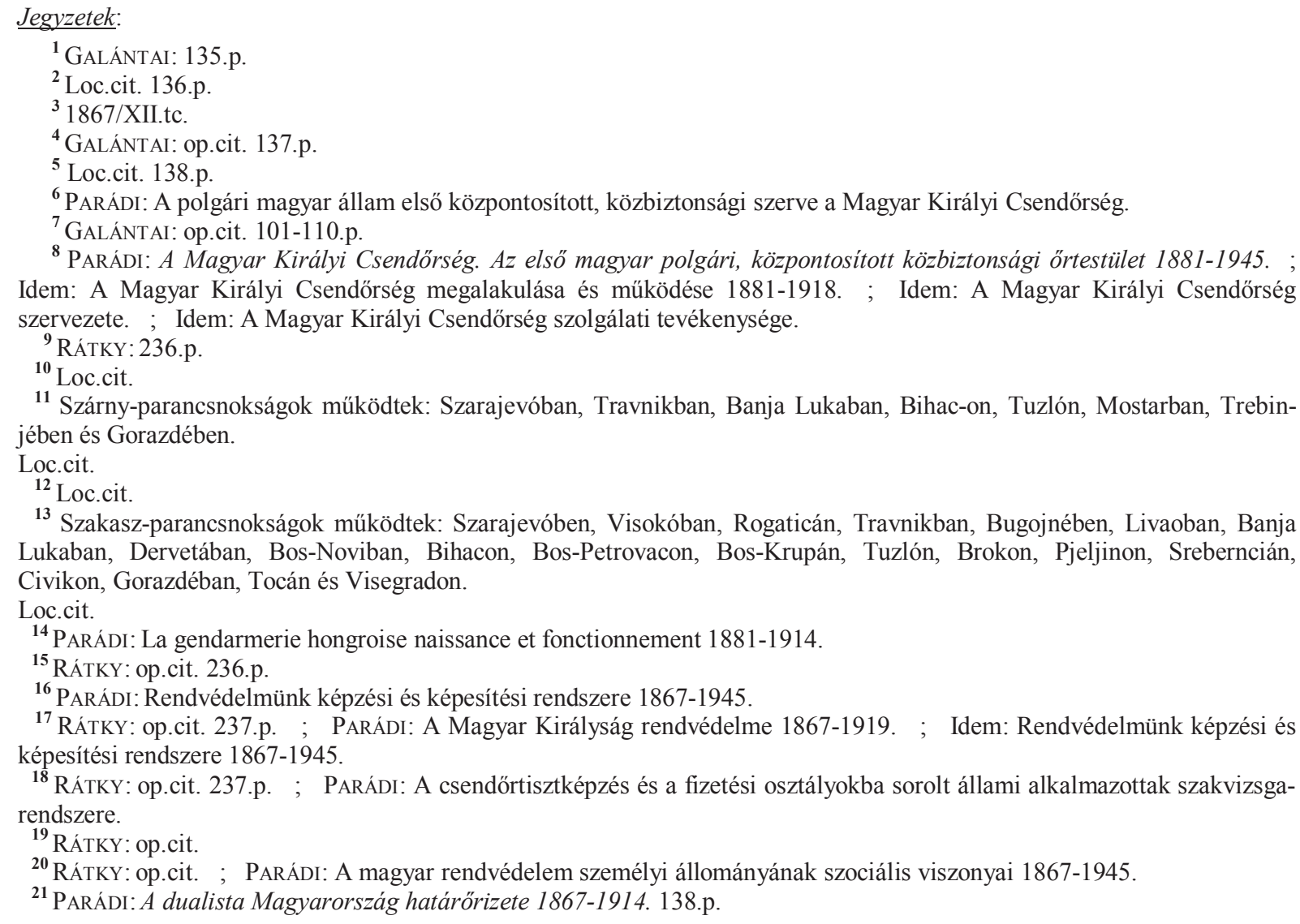




\section{Jegyzetekben alkalmazott röviditések:}

\section{MONOGRÁFIÁK, KISMONOGRÁFIÁK ÉS HASONLÓ JELLEGÜ KÖTETEK}

GALÁNTAI

PARÁdi: A Magyar Királyi Csendörség. Az elsö magyar polgári, központositott közbiztonsági örtestület 18811945.

\section{TANULMÁNYOK}

PARÁDI: A polgári magyar állam első központosított, közbiztonsági szerve a Magyar Királyi Csendőrség

PARÁDI: A Magyar Királyi Csendörség megalakulása és müködé-se 1881-1918.

PARÁDI: A Magyar Királyság rendvédelme 1867-1919.

PARÁDI: La gendarmerie hongroise naissance et fonctionnement 18811914.

PARÁDI: A magyar rendvédelem személyi állományának szociális viszonyai $1867-1945$.

PARÁDI: Rendvédelmünk képzési és képesítési rendszere 1867-1945.

PARÁDI: A csendőrtisztképzés és a fizetési osztályokba sorolt állami alkalmazottak szakvizsgarendszere.

PARÁDI: A Magyar Királyi Csendörség szervezete.
GALÁNTAI József: A Habsburg-monarchia alkonya. Osztrák-magyar dualizmus 1867-1918. Budapest, 1985, Kossuth. 387 p. HU-ISBN 9630925893.

PARÁDI József: A Magyar Királyi Csendörség. Az elsö magyar polgári, központositott közbiztonsági örtestület 1881-1945. Budapest, 2012, Szemere Bertalan Magyar Rendvédelem-történeti Tudományos Társaság. 281 p. HU-ISBN 978963084794 0. /A magyar rendvédelem-történet öröksége, 2./ HU-ISSN 2062-8447.

PARÁDI József: A polgári magyar állam első központosított, közbiztonsági szerve a Magyar Királyi Csendőrség. Belügyi Szemle, XXXVII.évf. (1982) 2.sz. 35-40.p. HU-ISSN 0133-6738.

PARÁDI József: A Magyar Királyi Csendőrség megalakulása és müködése 1881-1918. Rendvédelem-történeti Füzetek (Acta Historiae Praesidii Ordinis), VII. évf. (1997) 8.sz. 78-83.p. HU-ISSN 1216-6774. A tanulmány korábbi változata 1996. október 29-én Budapesten hangzott el a Szemere Bertalan Magyar Rendvédelem-történeti Tudományos Társaság által szervezett rendvédelem-történeti tudományos konferenciasorozatnak. „A napóleoni közbiztonsági örtestület útja Párizstól — Itálián és Ausztrián keresztül - Budapestig” címü VIII. konferenciáján. A publikált tanulmány az előadás javított, bővített és átdolgozott változata.

PARÁDI József: A Magyar Királyság rendvédelme 1867-1919. Rendvédelem-történeti Füzetek (Acta Historiae Praesidii Ordinis), X.évf. (1999) 10.sz. 98-147.p. HU-ISSN 1216-6774. A tanulmány korábbi változata 1998. szeptember 22-én Budapesten hangzott el a Szemere Bertalan Magyar Rendvédelem-történeti Tudományos Társaság által szervezett rendvédelemtörténeti tudományos konferenciasorozatnak ,A nyugati rendvédelem hatása a XIX-XX. századi magyar rendvédelemre” címú XI. konferenciáján. A publikált tanulmány az előadás javított, bővített és átdolgozott változata.

PARÁDI József: La gendarmerie hongroise naissance et fonctionnement 1881-1914. [A magyar csendőrség szervezete és müködése 1881-1914.] Revue de la gendarmerie nationale, LXXV.évf. (2002) 205.sz. 109-114.p. FR-ISSN 1243-5619.

PARÁD József: A magyar rendvédelem személyi állományának szociális viszonyai 1867-1945. Rendvédelem-történeti Füzetek (Acta Historiae Praesidii Ordinis), XV.évf. (2008) 17.sz. 57-64.p. HU-ISSN 1216-6774. A tanulmány korábbi változata 2003. november 11-én Budapesten hangzott el a Szemere Bertalan Magyar Rendvédelem-történeti Tudományos Társaság által szervezett rendvédelem-történeti tudományos konferenciasorozatnak a „A rendvédelem humán viszonyai" címü XVII. konferenciáján. A publikált tanulmány az előadás javított, bővített és átdolgozott változata.

PARÁDI József: Rendvédelmünk képzési és képesítési rendszere 18671945. Rendvédelem-történeti Füzetek (Acta Historiae Praesidii Ordinis), XIII.évf. (2007) 16.sz. 90-93.p. HU-ISSN 1216-6774. A tanulmány korábbi változata 2002. november 12-én Budapesten hangzott el a Szemere Bertalan Magyar Rendvédelem-történeti Tudományos Társaság által szervezett rendvédelem-történeti tudományos konferenciasorozatnak „A rendvédelmi szakképzés története" című XVI. konferenciáján. A publikált tanulmány az előadás javított, bővített és átdolgozott változata.

PARÁDI József: A csendőrtisztképzés és a fizetési osztályokba sorolt állami alkalmazottak szakvizsgarendszere. Rendvédelem-történeti Füzetek (Acta Historiae Praesidii Ordini), XIII. évf. (2007) 16.sz. 100-104.p. HU-ISSN 12166774. A tanulmány korábbi változata 2002. november 12-én hangzott el a Szemere Bertalan Magyar Rendvédelem-történeti Tudományos Társaság által szervezett rendvédelem-történeti tudományos konferenciasorozatnak „A rendvédelmi szakképzés története” címü XVI. konferenciáján. A publikált tanulmány az elöadás javított, bővített és átdolgozott változata.

PARÁDI József: A Magyar Királyi Csendőrség szervezete. Rendvédelemtörténeti Füzetek (Acta Historiae Praesidii Ordinis), XXI.évf. (2011) 24.sz. 8090.p. HU-ISSN 1216-6774 A tanulmány korábbi változata 2009. december 03án Budapesten hangzott el a Szemere Bertalan Magyar Rendvédelem-történeti Tudományos Társaság által szervezett rendvédelem-történeti tudományos konferencia-sorozatnak a „Csendőrség Ausztria-Magyarországon, illetve Ausztriában és Magyarországon 1849-2005. ” címü XXIV. konferenciáján. A publikált tanulmány az előadás javított, bővített és átdolgozott változata. 
PARÁDI: A Magyar Királyi Csendőrség szolgálati tevékenysége.

\section{CIKKEK}

RÁTKY

\section{KÉZIRATOK}

PARÁDI: A dualista Magyarország határörizete 1867-1914.

\section{JOGSZABÁLYOK}

1867/XII.tc.
PARÁDI József: A Magyar Királyi Csendőrség szolgálati tevékenysége. Rendvédelem-történeti Füzetek (Acta Historiae Praesidii Ordinis), XXI.évf. (2011) 24.sz. 90-99.p. HU-ISSN 1216-6774. A tanulmány korábbi változata 2009. december 3.-án, Budapesten hangzott el a Szemere Bertalan Magyar Rendvédelem-történeti Tudományos Társaság által szervezett rendvédelemtörténeti tudományos konferenciasorozatnak a „Csendőrség Ausztria-Magyarországon, illetve Ausztriában és Magyarországon 1849-2005." címü XXIV. konferenciáján. A publikált tanulmány az előadás javított, bővített és átdolgozott változata.

salamonfai RÁTKY Károly: A volt császári és királyi Bosznia-Hercegovina-i csendőr testület. Csendörségi Lapok, XV.évf. (1925) 13.sz. 236-237.p.

PARÁDI József: A dualista Magyarország határőrizete 1867-1914. Bölcsészdoktori disszertáció (ELTE BTK). Kézirat. Budapest, 1985.

1867/XII.tc. a Magyar Korona országai és az Ö Felsége uralkodása alatt álló többi országok között fennforgó közös érdekű viszonyokról, s ezek elintézésének módjáról.

\section{Mellékletek jegyzéke:}

I.sz. melléklet

Bosznia-Hercegovina csendőrségének szervezeti felépitése a dualizmus idöszakában.

II.sz. melléklet

Bosznia-Hercegovina csendörsége személyi állományának képzési rendszere.

\section{Bosznia-Hercegovina csendörségének szervezeti felépitése} a dualizmus idöszakában

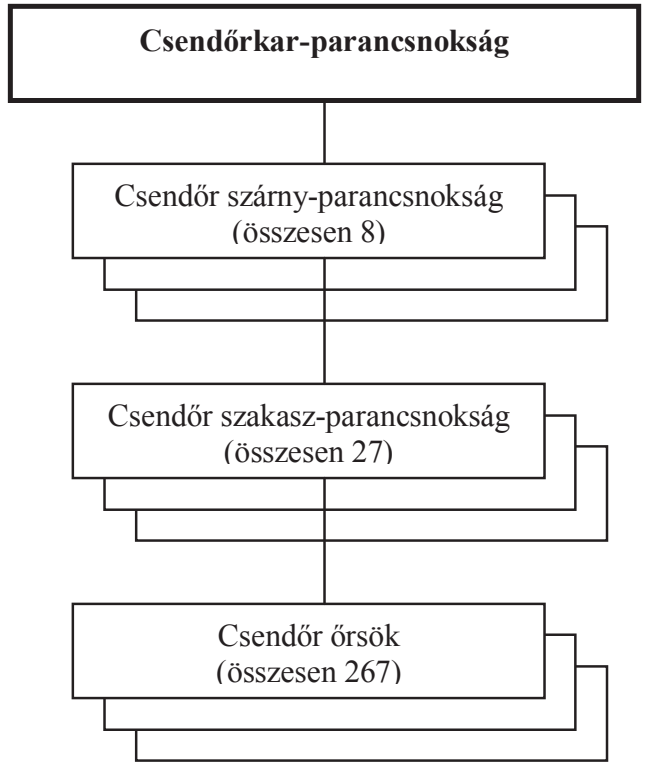

Forrás ! salamonfai RÁTKY Károly: A volt császári és királyi Bosznia-Hercegovina-i csendőr testület. Csendőrségi Lapok, XV.évf. (1925) 13.sz. 236-237.p. 
Bosznia-Hercegovina csendörsége személyi állományának képzési rendszere.

Kar-parancsnokság (tartományi parancsnokság)

JÁRÁSŐRMESTERI TANFOLYAM

Hat hetes időtartamú, oktatók törzs- és beosztott tisztek, jelentkezés 2-3 éves eredményes örs-parancsnoki müködés után.

ÖRS-PARANCSNOKI TANFOLYAM

Hat hónapos időtartamú, oktatók törzs- és beosztott tisztek, őrs-parancsnoki kinevezés előfeltétele a tanfolyam eredményes elvégzése. A tanfolyamot elvégzőket őrs-parancsnokhelyettessé, esetleg örs-parancsnokká nevezték ki

\section{Szárny-parancsnokság}

\section{PRÓBASZOLGÁLAT}

A haderőtől, illetve az Osztrák-Magyar Monarchia társcsendőr testületeitől átvett tisztek irányított szakmai felkészítése. Az egy éves próbaszolgálati idő a szár-parancsnok mentorálásával valósult meg, melynek a végén eredményes elméleti és gyakorlati vizsga nyomán véglegesítették a testületnél a tisztet.

\section{ALTISZTI TANFOLYAM}

Öt hónapos időtartamú, oktatók a szárny-parancsnokság székhelyén müködő szakasz-parancsnok és kiegészítő kiképzöként vezényelt altisztek. A tanfolyamra való bekerülés előfeltétele a járőrvezetői tanfolyam eredményes elvégzése. Altiszti rangba való elöléptetés feltétele volt az altiszti tanfolyam elvégzése. Továbbképző jellegü képzési forma volt ahol a kiválóan végzettek közül a legjobbakat őrsparancsnokhelyettesnek neveztek ki.

PRÓBACSENDÖR TANFOLYAM

Hat hónapos időtartamú, oktatók a szárny-parancsnokság székhelyén müködő szakasz-parancsnok és kiegészítő kiképzőként vezényelt altisztek. A tanfolyam járőrtársi képzettséget biztosító képzési forma, melyre katonaviseltek jelentkezhettek.

\section{Szakasz-parancsnokság}

\section{JÁRÖRVEZETÖI TANFOLYAM}

Három hónapos időtartamú, oktatók a szárny-parancsnokság székhelyén müködő szakasz-parancsnok és kiegészítö kiképzőként vezényelt altisztek. Járőrvezetőként kizárólag ezen tanfolyam eredményes elvégzését követően lehetett a csendőrt alkalmazni és tizedesnél magasabb rangba elöléptetni.

\section{Örs}

LEGÉNYSÉGI ÖNKÉPZÉS

Az örsök személyi állománya az örs elhelyezési körletében a típushelyzeteket vitatta meg az önképzésre szánt idő alatt az idősebb csendőrök vezetésével.

Forrás ! salamonfai RÁTKY Károly: A volt császári és királyi Bosznia-Hercegovina-i csendőr testület. Csendörségi Lapok, XV.évf. (1925) 13.sz. 236-237.p. 